Creative Commons User License: CC BY-NC-ND

Abstracted by: EBSCOhost, Electronic Journals Service (EJS), Google Scholar, Journal Seek, Scientific Commons,

Food and Agricultural Organization (FAO), CABI and Scopus
Journal of Agricultural Extension

Vol. 23 (1) January, 2019

ISSN(e): 24086851; ISSN(Print); 1119944X

http://journal.aesonnigeria.org

http://www.ajol.info/index.php/jae

Email: editorinchief@aesonnigeria.org

\title{
Beef Cattle Farmers' Group Cohesion in Bantul and Sleman Regencies Yogyakarta Special Region, Indonesia
}

https://dx.doi.org/10.4314/jae.v23i1.19

\section{Haryadi, Fransiskus Trisakti ${ }^{\star}$}

Laboratory of Communication and Community Development

Department of Livestock Socio-Economics Universitas Gadjah Mada

Email: trisakti-h@ugm.ac.id Phone:+628157950789

\section{Widiati, Rini}

Laboratory of Livestock Agribusiness Department of Livestock Socio-Economics Universitas GadjahMada

Email: rini w@ugm.ac.id Phone:+6282225085870

\section{Kusumastuti, Tri Anggraeni}

Laboratory of Livestock AgribusinessDepartment of Livestock Socio-Economics Universitas Gadjah Mada

Email: trianggraeni@ugm.ac.id Phone:+628156853631

\section{Andarwati, Siti}

Laboratory of Communication and Community Development

Department of Livestock Socio-Economics Universitas Gadjah Mada

Email: standarwat@gmail.com Phone: +628122757202

*Corresponding author

\section{Abstract}

The study analyze the cohesion level of beef cattle farmers' groups of Bismo in Bantul and Sido Makmur in Sleman Regencies Yogyakarta Special Region. All the active members of the groups were selected as respondents. The descriptive analysis was based on the components forming group cohesion including farmers' attractiveness to groups' goals, group activities, membership of the group, and interpersonal relationship among the members of the group. The results show that there was a difference in the kind of components in forming group cohesion between Bismo and Sido Makmur Groups. Bismo group had group activities as main attraction (95.98\%) for its members to commit to the group, while the membership of the group was the main indicator of attraction (97.33\%) for the member of Sido Makmur to stay in a group. Although the indicator of attractions was cohesion including interpersonal and farmers' group goal were in high score achievement percentage for both of the Groups of Bismo (89,81\% and $88.21 \%$ ) and Sido Makmur (88.98\% and $86.67 \%)$, but they had not been used optimally yet as the main reference by the farmers to commit to the groups. The study concluded that there was a high category level of beef cattle farmers' group cohesion for both Bismo and Sido Makmur groups. The farmers' group activities and membership of the group were the main indicators of attractions of beef cattle farmers' group cohesion. The government through their field extension workers should always improve beef cattle farmers' attitude towards the group goals.

Keywords: Attraction indicators, beef cattle farmers' group, group cohesion. 
Creative Commons User License: CC BY-NC-ND

Abstracted by: EBSCOhost, Electronic Journals Service (EJS),

Google Scholar, Journal Seek, Scientific Commons,

Food and Agricultural Organization (FAO), CABI and Scopus
Journal of Agricultural Extension

Vol. 23 (1) January, 2019

ISSN(e): 24086851; ISSN(Print); 1119944X

http://journal.aesonnigeria.org

http://www.ajol.info/index.php/jae

Email: editorinchief@aesonnigeria.org

http://eoi.citefactor.org/10.11226/v23i1

\section{Introduction}

One of the main commodities of livestock farming being the expectation to solve the problems for meeting demand of meat in Indonesia is beef cattle farming. In Indonesia, more than $90 \%$ of cattle population was raised by smallholder farmers (Atien et al., 2012). These cattle fulfil livelihood needs in smallholder mix farming system (Widi, 2015). The farmers are keeping their animals in small scale number of ownership as a side farming activities. And, this activity seems to be generating small additional incomes to the farmers in supporting farmers' welfare (Ryschawy, Choisis, Joannon, \& Gibon, 2012; Ntale and Litondo, 2013, Widiati, 2014).

To improve the performance of beef cattle smallholder farmers is intractable central issue for development of beef cattle farming in Indonesia. The main strategy to protect and empower the farmers in rural areas is by strengthening farmer organizations (Rasyid, 2015). All of the farmers are mobilized to be members of the farmer's groups to support the attainment of the program's goals. The Indonesia government has supported the strategy by establishing the policy of the guidance in giving an extension to farmers through the farmers' institution (The Law No. 19/2013 on the protection and empowerment of farmers in Indonesia).

Most of beef cattle farmers in Yogyakarta Region, especially in Sleman and Bantul Regencies, which are the large population of beef cattle in Yogyakarta Special Region, had organized themselves into formal organization as a farmers' group. But, the problem is some of them do not develop the groups as the government expects and this doesn't support the attainment of beef cattle program's goals. According to Widiati, et al. (2015), the local institutions record of the available farmers group put it at 423 groups in Sleman and 321 groups in Bantul, but no information was available on whether these groups are still active or inactive.

People come together to form groups not only for fellow feeling, but also for themselves (Ofuoku and Agbamu, 2012). The farmers form the group for their own common benefits. The degree to which members of a group desire to remain in the group is known as cohesion level. The cohesion is central to groups. Interpersonal attraction among members of a group could be viewed as a factor of someone commitment to the groups. The other factors that could be the causes of cohesion are attractiveness to group goals, activities, and status of member of the group. This paper tried to measure the cohesion level of beef cattle farmers' groups of Bismo in Bantul and Sido Makmur" in Sleman Regencies of Yogyakarta Special Region.

\section{Methodology}

The research was a case study carried out in beef cattle farmers' groups in Bantul and Sleman Regencies of Yogyakarta Special Region including Bismo and Sido Makmur groups, respectively. 
Creative Commons User License: CC BY-NC-ND

Abstracted by: EBSCOhost, Electronic Journals Service (EJS), Google Scholar, Journal Seek, Scientific Commons,

Food and Agricultural Organization (FAO), CABI and Scopus

http://eoi.citefactor.org/10.11226/v23i1
Journal of Agricultural Extension

Vol. 23 (1) January, 2019

ISSN(e): 24086851; ISSN(Print); 1119944X

http://journal.aesonnigeria.org

http://www.ajol.info/index.php/jae

Email: editorinchief@aesonnigeria.org
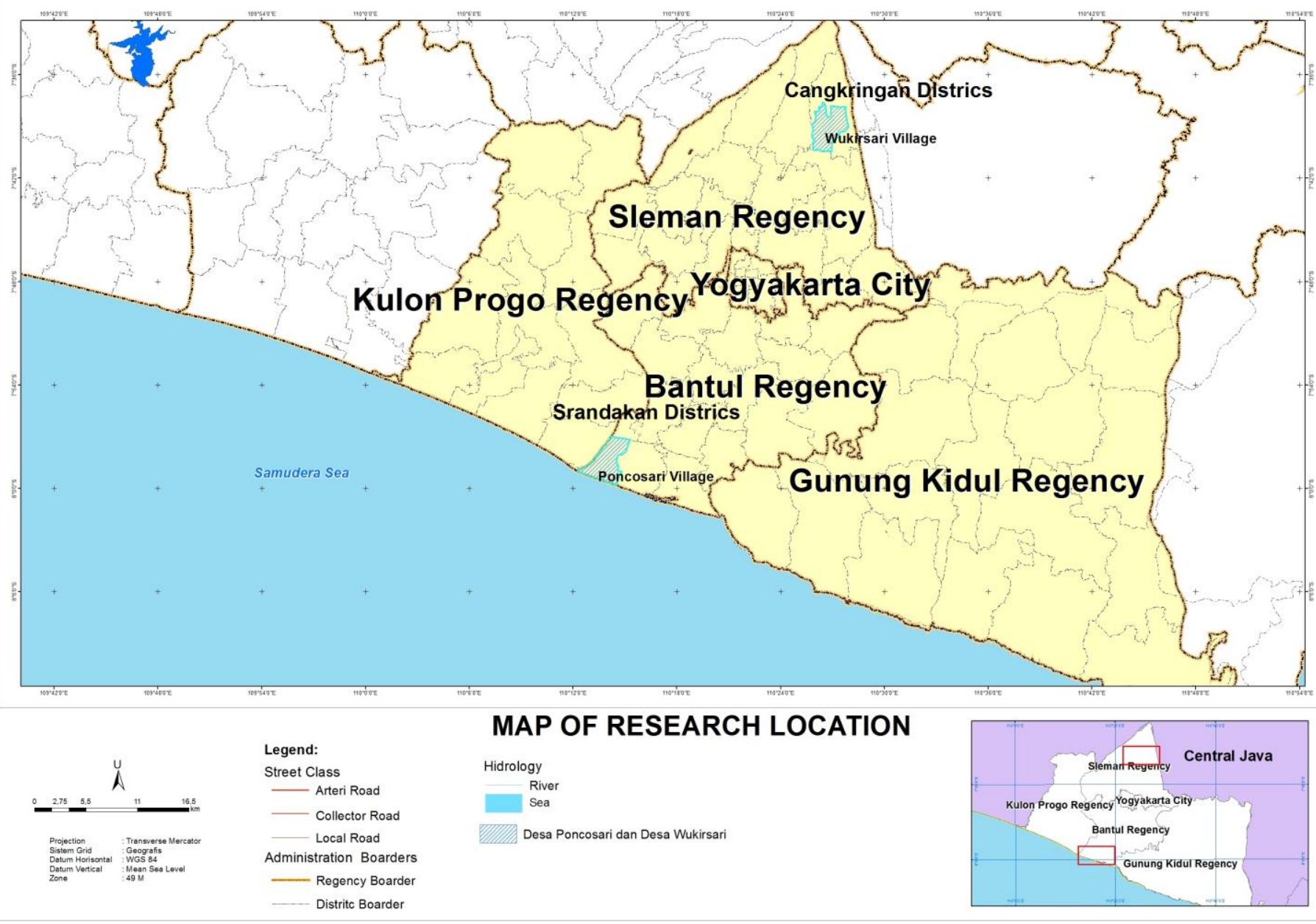

Figure 1. The map of research location.

Bismogroup is located at Poncosari Village. The latitude of Poncosari Village is -7.9733211 and the longitude is 110.2120499 . The village is in the southwest part of the sub-district, Srandakan, Bantul Regency (Figure 1). It is around $40 \mathrm{~km}$ from the central city of Yogyakarta Special Region. Although Poncosari Village is a coastal village on the Indian Ocean in Java, but the population predominantly works in agriculture and animal husbandry. Wukirsari Village is the place where Sido Makmur group is located. This village lies within latitude -7.6514621 and longitude 110.4292393. The village is $17 \mathrm{~km}$ eastern part from the capital city of Sleman Regency (Figure 1). It is at Northern part of Yogyakarta Special Region. Topographically, the village is located at an altitude of 450 to $600 \mathrm{~m}$ above sea level. It belongs to Merapi Mountain's slopes. Agricultural sector also has an important role in developing the village.

The farmers' groups were selected based on the best performance of beef cattle farmers' group in Bantul and Sleman Regencies assessed by Widiati et al. (2015). Farmers' group was used as a unit of analysis. All the active members of the groups were selected as the respondents. The data were collected by interviewing the respondent directly using questionnaire.

Variable of cohesion was measured by the indicators focused on the causes of cohesion (forces acting upon group members). Cohesion is regarded as the degree to which members of a group 
Creative Commons User License: CC BY-NC-ND

Abstracted by: EBSCOhost, Electronic Journals Service (EJS), Google Scholar, Journal Seek, Scientific Commons,

Food and Agricultural Organization (FAO), CABI and Scopus
Journal of Agricultural Extension

Vol. 23 (1) January, 2019

ISSN(e): 24086851; ISSN(Print); 1119944X

http://journal.aesonnigeria.org

http://www.ajol.info/index.php/jae

Email: editorinchief@aesonnigeria.org

desire to remain in the group, that is, how closely the members interact or the resultant forces acting on the member to remain in the group (Ofuoku and Agbamu, 2012). However, cohesion can also be considered as "attraction to collectivity" as opposed to an attraction to the individuals who make up that grouping. In this research, the attractions indicator of cohesion included interpersonal relationship among members of a group, membership of the group, group goals and group activities. Some questions were designed for each attractions indicator. Each question had three alternatives choices including supporting, neutral, and not supporting aspects of attraction indicators which scored by 3 to 1 . Level of group cohesion was calculated by percentage of the total score achievement from the maximum score. Maximum score was determined by the multiplication of the total number of questions and scores for each question and the total number of respondents of the each group. Descriptive analysis was used to explain the level of cohesion.

\section{Results and Discussions}

\section{Characteristics of Beef Cattle Farmers' Groups}

Table 1 shows the characteristics of the farmers being the member of the groups. The average age of farmers, both for Bismo and Sido Makmur groups, was still in productive age of $49.35 \pm 9.30$ and $49.52 \pm 10.67$, respectively. It meant that they could be expected to have the capability to develop their beef cattle farming for the future. Most of farmers, in Bismo (46.15\%) and Sido Makmur groups $(56.00 \%)$, had already completed elementary and secondary education, respectively. In all, more than $50 \%$ of the farmers had already finished Junior High School in both region

Table 1. Characteristics of beef cattle farmers' group

\begin{tabular}{|c|c|c|}
\hline \multirow[t]{2}{*}{ Characteristics } & \multicolumn{2}{|r|}{ Value } \\
\hline & Bismo Group $(n=25)$ & Sido Makmur Group $(\mathrm{n}=26)$ \\
\hline Average age (years) & $49.35 \pm 9.30$ & $49.52 \pm 10.67$ \\
\hline Formal education (\%): & & \\
\hline - Elementary School & 46.15 & 12.00 \\
\hline - Junior High School & 19.23 & 24.00 \\
\hline - Senior High School & 34.62 & 56.00 \\
\hline - Academy & - & 8.00 \\
\hline $\begin{array}{l}\text { Composition average number } \\
\text { of beef cattle raised (heads): }\end{array}$ & & \\
\hline - Bull & $0.54 \pm 1.33$ & $1.64 \pm 1.52$ \\
\hline - Steer & $0.15 \pm 0.37$ & $0.32 \pm 0.63$ \\
\hline - Cattle & $1.35 \pm 1.23$ & $0.72 \pm 0.79$ \\
\hline - Heifer & $0.23 \pm 0.43$ & $0.08 \pm 0.28$ \\
\hline - Calves & $0.42 \pm 0.64$ & $0.48 \pm 0.65$ \\
\hline $\begin{array}{l}\text { Average length experience of } \\
\text { beef cattle farming (years) }\end{array}$ & $20.92 \pm 17.98$ & $17.64 \pm 16.42$ \\
\hline $\begin{array}{l}\text { Average length being the beef } \\
\text { cattle group member (years) }\end{array}$ & $6.48 \pm 5.55$ & $6.84 \pm 3.97$ \\
\hline
\end{tabular}

Source: Field data (2016). 
Creative Commons User License: CC BY-NC-ND

Abstracted by: EBSCOhost, Electronic Journals Service (EJS),

Google Scholar, Journal Seek, Scientific Commons,

Food and Agricultural Organization (FAO), CABI and Scopus
Journal of Agricultural Extension

Vol. 23 (1) January, 2019

ISSN(e): 24086851; ISSN(Print); 1119944X

http://journal.aesonnigeria.org

http://www.ajol.info/index.php/jae

Email: editorinchief@aesonnigeria.org

The composition of beef cattle raised by the farmers, showed in Table 1 indicated that breeding and fattening were the type of beef cattle farming for both of Bismo and Sido Makmur groups. Based on the number of cattle raised, their beef cattle farming can be categorized as smallholder farmers. It was in accordance with Widi (2015) statement that beef cattle smallholder farming system was characterized by less than 5 heads of cattle per household. Although they are categorized as smallholder farmers, but the average years of experience for beef cattle farming was more than 15 years (Table 1). The farmers had been organized in the farmers' group, but they had not been relatively so long with the average length of 6.48 years and 6.84 years for Bismo and Sido Makmur groups, respectively (Table 1).

\section{Cohesion Level of Beef Cattle Farmers' Groups}

Table 2 shows that the cohesion level of beef cattle farmers' group was in high category, both for Bismo and Sido Makmur groups. Score achievement of cohesion for Bismo group (91.91\%) was a bit higher than Sido Makmur group (91.76\%) (Table 2). It meant that farmers who were the members of Bismo group had a little bit stronger commitment to their group than farmers who were the member of Sido Makmur group.

Table 2. Cohesion indicators and level of cohesion

\begin{tabular}{lcclcc}
\hline \hline \multirow{2}{*}{$\begin{array}{l}\text { Attraction Indicators } \\
\text { of Cohesion }\end{array}$} & \multicolumn{2}{c}{ Bismo Group } & & \multicolumn{2}{c}{ Sido Makmur Group } \\
\cline { 2 - 3 } \cline { 5 - 6 } $\begin{array}{c}\text { \% Score } \\
\text { Achievement }\end{array}$ & Ranking & & $\begin{array}{c}\text { \% Score } \\
\text { Achievement }\end{array}$ & Ranking \\
\hline Interpersonal & 89.81 & 3 & & 88.98 & 3 \\
Membership & 95.30 & 2 & & 97.33 & 1 \\
Group goals & 88.21 & 4 & & 86.67 & 4 \\
Group activities & 95.94 & 1 & & 96.89 & 2 \\
\hline Level of cohesion & 91.91 & & & 91.76 & \\
\hline
\end{tabular}

Table 2 also shows that there were different kinds of indicators of attractions for cohesion which were the highest ranking of score achievement percentage. Group activities attraction indicator was the highest score achievement (95.94\%) for Bismo group, while Sido Makmur group had the highest score achievement (97.33\%) in membership attraction (Table 2). Most of the member of Bismo group had a good attraction regarding the management activities which were organized by the farmers' group. It meant that most of the member of Bismo group joined voluntarily the activities organized by the group. It was also indicated that the farmers' group ensured facility for their group members to get involved in performing some activities organized by the group. Gyau et al. (2012) stated that the easier for farmers to participate in group activities, the more the farmers will rank an initiative higher.

The different attraction indicators of cohesion were found for Sido Makmur group. Most of the members of the group had a high attraction in membership of beef cattle farmers' group $(97.33 \%)$ (Table 2). This finding indicated that the members of Sido Makmur group had a good awareness and voluntarily responded that they had invested part of themselves to become a member of the group. They expected that they could get economic benefit after being the member of the group. The expectation of getting benefit from the membership of the group was one of the most important factors that motivate farmers to take part in associations. The result of the research from 
Creative Commons User License: CC BY-NC-ND

Abstracted by: EBSCOhost, Electronic Journals Service (EJS),

Google Scholar, Journal Seek, Scientific Commons,

Food and Agricultural Organization (FAO), CABI and Scopus
Journal of Agricultural Extension

Vol. 23 (1) January, 2019

ISSN(e): 24086851; ISSN(Print); 1119944X

http://journal.aesonnigeria.org

http://www.ajol.info/index.php/jae

Email: editorinchief@aesonnigeria.org

http://eoi.citefactor.org/10.11226/v23i1

ljioma and Osondu (2015) revealed that the membership of association was an important factor to determine the level of amount of agricultural credit acquired by farmers. Furthermore, Chekene and Chancellor (2015) found that most of the farmers had more access to some facilities such as credit and extension contact when they were the member of the association.

Table 2 also indicates that attraction of beef cattle farmers' group goals was the least ranked $\left(4^{\text {th }}\right.$ ranking) as the indicator component of cohesion for both Bismo and Sido Makmur groups. It meant that group goals had not been used as the main indicator of attractions by most of members of farmers' groups to commit to the beef cattle farmers' group. Aminah (2016) stated that the role of the knowledge of external agent (government officials, assistant, and expert) is still dominant in establishing the farmer organizations. The farmers' group had a consensus regarding the group goals, but most of the members said that the original source of the goals mostly came from the government through the field extension workers.

\section{Conclusion and Recommendations}

There was a high category level of beef cattle farmers' group cohesion for both Bismo and Sido Makmur groups. Farmers who were the members of the groups had high commitment to their groups.

All of indicators of attractions of cohesion had high score achievement percentages. Group activities and membership of the group attractions were the most important indicators for the members of beef cattle farmers' groups to commit to their groups. The government through their field extension workers should always improve beef cattle farmers' attitude towards the group goals, so that the sustainability of farmers' group dynamic also could be improved.

\section{Acknowledgement}

We are grateful to all members of the farmers' groups that participated in this research through their sharing of experience and information regarding beef cattle farming in the group. We would also like to thank to Ministry of Research, Technology and Higher Education Republic of Indonesia for funding support for the research through grants No. 015/SP2H/LT/DRPM/II/2016.

\section{References}

Atien, P., Hanifah, V. W., Mahendri, I. G. A. P., Cahyadi, F., \& Cramb, R. A. (2012). Small-scale beef cattle production in East Java, Indonesia. Paper presented at the 56th Australian Agricultural and Resource Economics Society annual conference, Fremantle, Western Australia, February 7-10, 2012.

Chekene, M.B. and Chancellor, T.S.B. (2015). Factors affecting the adoption of improved rice varieties in Borno State, Nigeria. Journal of Agricultural Extension. Vol 19(2), 21-33.

Gyau, A., Takoutsing, B., Degrande, A., and Franzel, S. (2012). Producers' motivation for collective action for kola production and marketing in Cameroon. Journal of Agriculture and Rural Development in the Tropics and Subtropics, Vol. 113 (1):43-50. 
Creative Commons User License: CC BY-NC-ND

Abstracted by: EBSCOhost, Electronic Journals Service (EJS), Google Scholar, Journal Seek, Scientific Commons,

Food and Agricultural Organization (FAO), CABI and Scopus
Journal of Agricultural Extension

Vol. 23 (1) January, 2019

ISSN(e): 24086851; ISSN(Print); 1119944X

http://journal.aesonnigeria.org

http://www.ajol.info/index.php/jae

Email: editorinchief@aesonnigeria.org

http://eoi.citefactor.org/10.11226/v23i1

ljioma, J.C. and Osondu, C.K. (2015). Agricultural credit sources and determinats of credit acquisition by farmers in Idemili Local Government area of Anambra State. Journal of Agricultural Science and Technology, B 5:34-43.

Ntale, J. F and Litondo, K. O. (2013). Determinats of commercial mixed farming on small farms in Kenya. European Journal of Business and Management, Vol. 5(22):47-54.

Ofuoku,A.U. and Agbamu, J. U. (2012). Influence of farmers' group cohesion on adoption of climate change adaptation strategies in Delta State, Nigeria. Global Journal of Science Frontier Research Agriculture and Veterinary Sciences, Vol. 12 Issue 6 Version 1.0 April 2012.

Rasyid, F.A. (2015). Agriculture extension in Indonesia: moving towards farmer empowerment. National Center of Agricultural Extension, Ministry of Agriculture Republic of Indonesia. Retrieved from http://www.comcec.org/wp-content/uploads/2015/08/Indonesia.pdf

Ryschawy, J., Choisis, N., Joannon, A., and Gibon. (2012). Mixed crop-livestock systems: an economic and environmental-friendly way of farming? Animal Vol. 6(10):1722-1730.

Widiati, R. (2014). Developing beef cattle industry at smallholders to support beef self-sufficiency. Wartazoa Vol. 24(4):191-200.

Widiati, R., Kusumastuti, T. A., Haryadi, F. T., and Andarwati, S. (2015). Penguatan pemberdayaan Kelompok Peternak Sapi Potong Rakyat Berbasis Lembaga Keuangan Mikro untuk Mendukung Kemandirian Pangan. LPPM, UGM. Research report (Unpublished).

Widi, TSM. (2015). Mapping the impact of crossbreeding in smallholder cattle systems in Indonesia. $\quad \mathrm{PhD}$ thesis, Wageningen University, Wageningen. Retrieved from https://library.wur.nl/WebQuery/wurpubs/fulltext/345219 